\title{
TUJUAN PENDIDIKAN DALAM AL-QUR'AN
}

\author{
Oleh : Mardiah ${ }^{100}$
}

\begin{abstract}
Abstrak
Tujuan mengembangkan segala potensi bawaan manusia secara integral, silmutan dan berkelanjutan agar manusia mampu melaksanakan tugas dan kewajiban dalam kehidupan ini guna mencapai kebahagian di masa sekarang dan masa mendatang. Adapun bentuk-bentuk tujuan pendidikan dalam al-Quran adalah sebagai berikut: Agar manusia menjadi hamba Allah SWT, Agar manusia mampu menjalankan fungsinya sebagai khalifah Allah fi al-Ardh, agar manusia berfikir dan menggunakan akalnya, agar manusia memiliki ilmu pengetahuan dan meninggikan derajatnya, dan supaya manusia mendapatkan kesejahteraan dan kebahagian hidup di dunia dan di akhirat.
\end{abstract}

\section{Kata Kunci : Tujuan Pendidikan, Al-Qur'an}

\section{Pendahuluan}

Al-Quran menceritakan banyak hal tentang pendidikan dan urgensinya bagi kehidupan manusia. Pada hakikatnya seluruh ayat yang terdapat dalam alQuran mengandung nilai-nilai pendidikan yang sangat bermanfaat bagi mereka yang mempelajari dan menggalinya dengan potensi akal yang dimiliki. Karena pendidikan itu sendiri secara umum merupakan "usaha sadar dan terencana untuk mewujudkan suasana belajar dan proses pembelajaran agar peserta didik secara aktif mengembangkan potensi dirinya untuk memiliki kekuatan spritual keagamaan, pengendalian diri, kepribadian, kecerdasan, akhlak mulia, serta keterampilan yang diperlukan dirinya, masyarakat, bangsa dan negara". ${ }^{101}$

\footnotetext{
${ }^{100}$ Dosen Tetap Program Studi Pendidikan Guru Madrasah Ibtidaiyah Agama STAI Auliaurrasyidin Tembilahan Kabupaten Indragiri Hilir Propinsi Riau.

${ }^{101}$ Undang-Undang Republik Indonesia Nomor 20 Tahun 2003 Tentang Sistem Pendidikan Nasional (Sisdiknas), (Bandung: Citra Umbara, 2003), h. 60-61. Terdapat beberapa hal yang perlu diuraikan tentang konsep pendidikan yang terdapat dalam Undang90
} 
Sedangkan secara khusus, pendidikan adalah usaha sadar dan terencana sebagaimana yang dicita-citakan oleh al-Quran itu sendiri yang menghendaki agar umatnya senantiasa menjalani hidup dan kehidupannya di dunia berdasarkan ketentuan-ketentuan yang telah ditentukan al-Quran dan didukung oleh hadis-hadis Rasulullah SAW agar memperoleh kehidupan yang bahagia di dunia dan akhirat kelak.

Pendidikan sebagai sebuah sistem mengandung sejumlah komponen yang saling berkaitan antara satu dengan lainnya dan bekerjasama dalam satu kesatuan secara seimbang dan serasi. Di antara komponen yang dimaksud dalam sistem pendidikan adalah tujuan pendidikan. ${ }^{102}$ Tujuan ini merupakan muara dari semua proses pendidikan yang dilakukan. Demikian halnya al-Quran, juga telah menggariskan tujuan pendidikan sebagai arah yang harus dituju oleh setiap pribadi muslim dalam menempuh kehidupannya di muka bumi. Dengan adanya tujuan pendidikan

Undang tersebut. Pertama, Pendidikan adalah Usaha sadar yang terencana, hal ini berarti proses pendidikan bukanlah proses yang dilaksanakan secara asal-asalan dan untunguntungan, akan tetapi proses yang bertujuan sehingga segala sesuatu yang dilakukan oleh guru dan siswa diarahkan pada pencapaian tujuan. Kedua, Proses yang terencana itu diarahkan untuk mewujudkan suasana belajar dan proses pembelajaran, hal ini berarti pendidikan tidak boleh mengesampingkan proses belajar. Pendidikan tidak semata-mata berusaha untuk mencapai hasil belajar, akan tetapi bagaimana memperoleh hasil atau proses belajar yang terjadi pada diri anak. Ketiga, Suasana belajar dan pembelajaran itu diarahkan agar peserta didik dapat mengembangkan potensi dirinya, ini berarti proses pendidikan itu harus berorientasi pada siswa. Pendidikan adalah upaya pengembangan potensi anak didik. Dengan demikian anak harus dipandang sebagai organisme yang sedang berkembang dan memiliki potensi.Keempat, akhir dari proses pendidikan adalah kemampuan anak memiliki kekuatan spritual keagamaan, pengendalian diri, masyarakat, bangsa dan negara. Hal ini berarti bahwa proses pendidikan berujung pada penbentukan sikap, pengembangan kecerdasan atau intelektual, serta pengembangan keterampilan anak yang sesuai dengan kebutuhan. Lihat Wina Sanjaya, Strategi Pembelajaran, (Jakarta: Kencana Prenada Media Group, 2006), h. 2-3

${ }^{102}$ Dalam Undang-Undang No. 20 tahun 2003 tentang Sisdiknas, pada bab 2 pasal 3 menyatakan bahwa tujuan Pendidikan Nasional adalah untuk mengembangkan potensi peserta didik agar menjadi manusia yang beriman dan bertakwa kepada Tuhan Yang Maha Esa, berakhlak mulia, sehat, berilmu, cakap, kreatif, mandiri, dan menjadi warga Negara yang demokratis serta bertanggung jawab. Lihat Undang-Undang RI No. 20 tahun 2003, Sisdiknas, Ibid., h. 5-6 
dalam al-Quran, berarti setiap muslim sudah memiliki orientasi yang sangat jelas dan mantap serta tingkat kesadaran yang lebih tinggi.

\section{Tujuan Pendidikan Dalam Al-Quran}

\section{Pengertian Tujuan}

Ramayulis menjelaskan bahwa istilah "tujuan" atau "sasaran" atau "maksud", dalam bahasa Arab dinyatakan dengan ghayat atau ahdaf atau maqasid. Sedangkan dalam bahasa Inggris, istilah "tujuan" dinyatakan dengan "goal atau "purpose" atau "objective" atau "aim”. Secara umum istilah-istilah itu mengandung pengertian yang sama, yaitu arah suatu perbuatan atau yang hendak dicapai melalui upaya atau aktivitas. ${ }^{103}$

Sedangkan secara lebih spesifik, Mohammad Ansyar merincikan sebagai berikut: Aim menunjukkan arah secara umum. Secara ideal, aim merefleksikan suatu tingkat tujuan pendidikan berdasarkan pemikiran filosofis dan psikologis masyarakat. Dengan perkataan lain, aim adalah statemen tentang hasil kehidupan yang diharapkan (expected life outcomes) berdasarkan pada skema nilai filsafat hidup. Aim dalam hal ini dapat disamakan dengan "tujuan pendidikan nasional" di negara Indonesia.

Untuk mencapai tujuan umum (aim) perlu ditentukan pula tujuan yang lebih spesifik dari aim tersebut yang dinamakan dengan goal. Goal merupakan tujuan yang terletak antara aim dan objective (objektif). Dengan perkataan lain, goal adalah hasil proses belajar menurut suatu sistem sekolah. Goal lebih umum dari objective dan bukan merupakan hasil langsung proses belajar dalam ruang kelas dan untuk pencapaiannya memerlukan seperangkat objectives. Contohnya, apresiasi kesusastraan, kemampuan berpikir analitik dan berpikir kritis, dan lain sebagainya.

\footnotetext{
${ }^{103}$ Ramayulis, Ilmu Pendidikan Islam, (Jakarta: Kalam Mulia, 2013), h.209, lihat juga Abdurrahman Saleh Abdullah, Teori-teori Pendidikan Berdasarkan al-Quran, (Jakarta: Rineka Cipta, 2005), h. 132
}

92 
Seringkali di Indonesia, goal ini disamakan dengan tujuan kurikulum sekolah atau tujuan institusional. ${ }^{104}$

Menurut Zakiah Daradjat, tujuan merupakan sesuatu yang diharapkan tercapai setelah suatu usaha atau kegiatan selesai. ${ }^{105}$ Sehubungan dengan tujuan ini, H.M. Arifin ${ }^{106}$ menjelaskan bahwa tujuan bisa jadi menunjukkan kepada futuritas (masa depan) yang terletak pada suatu jarak tertentu yang tidak dapat dicapai kecuali dengan usaha melalui proses tertentu. Meskipun banyak pendapat tentang pengertian tujuan, akan tetapi pada umumnya pengertian itu berpusat pada usaha atau perbuatan yang dilaksanakan untuk suatu maksud tertentu.

Berdasarkan penjelasan-penjelasan di atas, maka dapat dipahami bahwa baik secara umum maupun secara khusus (spesifik) tujuan adalah sesuatu yang hendak dicapai atau diharapkan setelah melakukan sesuatu. Tentunya tujuan yang hendak dicapai itu adalah tujuan yang baik dan sempurna.

\section{Pengertian Tujuan Pendidikan}

Menurut Suardi tujuan pendidikan adalah seperangkat hasil pendidikan yang dicapai oleh peserta didik setelah diselenggarakan kegiatan pendidikan. Seluruh kegiatan pendidikan, yakni bimbingan pengajaran atau latihan, diarahkan untuk mencapai tujuan pendidikan itu. Dalam konteks ini tujuan pendidikan merupakan komponen dari sistem pendidikan yang menempati kedudukan dan fungsi sentral. Itu sebabnya setiap tenaga pendidikan perlu memahami dengan baik tujuan pendidikan. ${ }^{107}$

\footnotetext{
${ }^{104}$ Mohammad Ansyar, Dasar-Dasar Pengembangan Kurikulum, (Jakarta: Direktorat Jenderal Pendidikan Tinggi, 1989), h. 93-94

${ }^{105}$ Zakiah Daradjat, Ilmu Pendidikan Islam, (Jakarta: Bumi Aksara, 1992), h. 29

${ }^{106}$ H.M. Arifin, Ilmu Pendidikan Islam: Suatu Tinjauan Teoritis dan Praktis Berdasarkan Pendekatan Interdisipliner, (Jakarta: Bumi Aksara, 1991), h. 223

${ }^{107}$ M.Suardi, Pengantar pendidikan teori dan aplikasi,(Jakarta: PT Indeks, 2010),

h. 7
} 


\section{Bentuk-bentuk Tujuan Pendidikan dalam Al-Quran}

Adapun tujuan pendidikan dalam al-Quran, di antaranya adalah:

a. Agar Manusia Menjadi Hamba Allah SWT

Allah SWT berfirman dalam al-Quran yang artinya:

"Dan aku tidak menciptakan jin dan manusia melainkan supaya mereka mengabdi kepada-Ku. (Q.S adz-Dzariyat: 56) ${ }^{108}$ dalam ayat yang lain Allah SWT berfirman yang artinya: "Hai manusia, sembahlah Tuhanmu yang telah menciptakanmu dan orang-orang yang sebelummu, agar kamu bertakwa" (Q.S al-Baqarah: 21) ${ }^{109}$

Quraish Shihab juga menjelaskan mengenai ayat-ayat di atas, pada ayat 56 surah adz-Dzariyat dijelaskan bahwa Dan Aku tidak menciptakan jin dan manusia untuk satu manfaat yang kembali kembali kepada diri-Ku.Aku tidak menciptakan merekamelainkan agar tujuan atau kesudahan aktivitas mereka adalah beribadah kepada-Ku. ${ }^{110}$ Pada ayat 21 surah al-Baqarah dijelaskan pula bahwa Wahai seluruh manusia yang mendengar panggilan ini beribadahlah, yakni tunduk, patuh dengan penuh hormat, dan kagumlah kepada Tuhan kamu Sang Pemelihara dan Pembimbing, karena Dia-lah yang menciptakan kamu dan orang-orang yang sebelum kamu, agar kamu bertakwa. ${ }^{111}$

Menurut Abas dari ayat-ayat di atas dapat dipahami bahwa peran utama manusia di dunia ini adalah sebagai hamba Allah SWT ('abd Allah). Maka esensialnya kata 'abd (hamba) adalah ketaatan, 2012), h. 524

${ }^{108}$ Departemen Agama, Al-Quran dan Terjemahan, (Jakarta: Zikrul Hakim,

${ }^{109}$ Ibid., h. 5

${ }^{110}$ M.Quraish Shihab, Tafsir Al-Misbah: Pesan, Kesan, dan Keserasian AlQuran, (Jakarta: Lentera Hati, 2002), Vol. 13, h. 355

${ }^{111}$ M.Quraish Shihab, Tafsir Al-Misbah: Pesan, Kesan, dan Keserasian AlQuran, (Jakarta: Lentera Hati, 2002), Vol. 1, h. 119 
ketundukan dan kepatuhan. Dan ketaatan, ketundukan dan kepatuhan manusia hanya layak diberikan kepada Allah SWT. ${ }^{112}$

Lebih lanjut Muhammad Nasib Ar-Rifa'i menjelaskan bahwa bila mereka telah menserikatkan peribadatan kepada yang selain Aku, maka kemurkaan-Ku akan segera menimpa mereka. Akan tetapi, bila mereka mentauhidkan Aku di dalam peribadatan, maka Aku akan meridhai mereka dan akan memasukkan mereka ke dalam syurgaKu. ${ }^{113}$ Sehingga menurut Imam Qurthubi makna utama untuk kata (لَيَعْبُدُون)pada firman diatas (surah Adz-Dzariyat ayat 56) adalah agar mereka tunduk, patuh, dan melakukan peribadatan. ${ }^{114}$

Berdasarkan ayat-ayat dan uraian-uraian di atas, maka dapat dipahami bahwa tujuan pendidikan dalam al-Quran itu adalah membina manusia menjadi hamba Allah SWT., dengan tugas atau peran utamanya adalah beribadahanya kepada Allah SWT. Sebagaimana firman-Nya yang artinya:

"Katakanlah: Sesungguhnya shalatku, ibadatku, hidupku dan matiku hanyalah untuk Allah, Tuhan semesta alam”. (Q.S al-An'am: 162) ${ }^{115}$

Quraish Shihab menjelaskan bahwa ayat ini merupakan gambaran tentang sikap nabi Muhammad SWA., yang mengajak kaumnya untuk beriman. Ayat ini memerintahkan: katakanlah Wahai Muhammad SAW bahwa, sesungguhnya shalatku, dan semua ibadahku termasuk korban dan penyembelihan binatang yang kulakukan dan, hidupku bersama segala yang terkait dengannya, baik tempat, waktu, maupun aktivitas dan matiku, yakni iman dan amal saleh yang akan ku

${ }^{112}$ Abbas Asyafah, Proses Kehidupan Manusia dan Nilai Eksistensialnya, (Bandung: Alfabeta, 2009), h. 57

${ }^{113} \mathrm{Ibid}$.

${ }^{114}$ Syaikh Imam Al-Qurthubi, Tafsir Al-Qurthubi, (Jakarta:PustakaAzzam, 2009),h. 296

${ }^{115}$ Departemen Agama,op.cit., h. 151 
bawa mati, kesemuanya kulakukan secara ikhlas dan murni hanyalah semata-matauntuk Allah, Tuhan Pemelihara semesta alam. ${ }^{116}$

Salah satu tujuan pendidikan dalam al-Quran adalah agar manusia menjadi hamba Allah SWT.Menurut Ramayulis Tujuan ini sejalan dengan tujuan hidup dan penciptaan manusia, yaitu semata-mata untuk beribadah kepada Allah SWT. ${ }^{117}$ Ibadah menurut Gulen adalah menghabiskan hidup dengan melaksanakan perintah-perintah dan taklif dari Allah SWT. ${ }^{118}$

Agar tujuan ini dapat tercapai sesuai dengan yang diharapkan, maka pendidikan al-Quran berusaha membawa dan mengarahkan peserta didiknya lewat sentuhan terhadap potensi yang dimilikinya, mengenal, mengimani, dan senantiasa berbuat semata-mata karena rasa ketundukannya kepada Zat Yang Maha Kuasa. Dengan rasa ketaatan dan kerinduan ini, diharapkan akan mampu diketahui ajaran-ajaran Tuhannya dengan penuh penghayatan, sehingga seluruh aktivitasnya merupakan pencerminan dari ketundukan dan kepatuhan kepada Allah SWT.

b. Agar Manusia Mampu Menjalankan Fungsinya Sebagai Khalifah Allah $f i$ al-Ardh

Allah SWT telah memposisikan manusia dalam hubungannya dengan sesama makhluk sebagai khalifah di bumi. Posisi itu telah diisyaratkan oleh Allah SWT dalam al-Quran yang artinya:

"Dan ingatlah ketika Tuhanmu berfirman kepada Para Malaikat: "Sesungguhnya aku hendak menjadikan seorang khalifah di muka bumi." mereka berkata: "Mengapa Engkau hendak menjadikan (khalifah) di bumi itu orang yang akan membuat kerusakan padanya dan

${ }^{116}$ M.Quraish Shihab, Tafsir Al-Misbah: Pesan, Kesan, dan Keserasian AlQuran, (Jakarta: Lentera Hati, 2002), Vol. 4, h. 369

${ }^{117}$ Ramayulis, Ibid., h.211

${ }^{118}$ Muhammad Fethullah Gulen, Tasawuf Untuk Kita Semua: Menapaki Bukitbukit Zamrud Kalbu Melalui Istilah dalam Praktik Sufisme, Terj. Fuad Syarifuddin Nur, (Jakarta: Republika, 2013), h. 111 
menumpahkan darah, Padahal Kami Senantiasa bertasbih dengan memuji Engkau dan mensucikan Engkau?" Tuhan berfirman: "Sesungguhnya aku mengetahui apa yang tidak kamu ketahui." (Q.S alBaqarah: 30) ${ }^{119}$

Quraish Shihab menjelaskan bahwa kata khalifah (خليفة) pada mulanya berarti yang menggantikan atau yang datang sesudah siapa yang datang sebelumnya. Atas dasar ini ada yang memahami kata khalifah di sini dalam arti yang menggantikan Allah SWT dalam menegakkan kehendak-Nya dan menerapkan ketetapan-ketetapan-Nya, tetapi bukan karena Allah SWT tidak mampu atau menjadikan manusia berkedudukan sebagai Tuhan, namun karena Allah SWT bermaksud menguji manusia dan memberinya penghormatan. Ada lagi yang memahaminya dalam arti yang menggantikan makhluk lain dalam menghuni bumi ini. ${ }^{120}$

Keterangan ayat di atas menunjukkan bahwa tujuan pendidikan yang ingin dicapai al-Quran adalah membina manusia agar mampu menjalankan fungsinya sebagai khalifah Allah SWT di muka bumi ini. Walaupun manusia itu di beri amanah sebagai khalifah, yang diserahi tugas dan wewenang oleh Allah SWT. Namun, di dalam menjalankan tugas kekhalifahannya harus sesuai dengan petunjuk Allah SWT yang memberi tugas dan wewenang tersebut.

c. Agar Manusia Berfikir dan Menggunakan Akalnya

Allah SWT berfirman dalam al-Quran yang artinya:

"Sesungguhnya dalam penciptaan langit dan bumi, silih bergantinya malam dan siang, bahtera yang berlayar di laut membawa apa yang berguna bagi manusia, dan apa yang Allah turunkan dari langit berupa air, lalu dengan air itu Dia hidupkan bumi sesudah mati (kering)-nya dan Dia sebarkan di bumi itu segala jenis hewan, dan pengisaran angin

\footnotetext{
${ }^{119}$ Departemen Agama, op.cit., h. 7

${ }^{120}$ M.Quraish Shihab, Tafsir Al-Misbah ..., Vol. 1,op.cit., h. 142
} 
dan awan yang dikendalikan antara langit dan bumi; sungguh (terdapat) tanda-tanda (keesaan dan kebesaran Allah) bagi kaum yang memikirkan". (Q.S al-Baqarah: 164)

Qurais Shihab menjelaskan bahwa ayat ini mengundang manusia untuk berfikir dan merenung tentang sekian banyak hal, yaitu: ${ }^{122}$ 1) Berfikir dan merenung tentang penciptaan langit dan bumi. Yang dimaksud dengan langit adalah benda-benda angkasa seperti matahari, bulan dan jutaan gugusan bintang-bintang yang kesemuanya beredar dengan sangat teliti dan teratur.

2) Merenungkan pergantian malam dan siang. Yakni perputaran bumi dan porosnya yang melahirkan malam dan siang serta perbedaannya, baik dalam masa maupun dalam panjang serta pendek siang dan malam.

3) Merenungkan tentang bahtera-bahtera yang berlayar di laut, membawa apa yang berguna bagi manusia. Ini mengisyaratkan sarana transportasi, baik yang digunakan masa kini dengan alat-alat canggih maupun masa lampau yang hanya mengandalkan angin dengan segala akibatnya.

4) Merenungkan tentang apa yang Allah turunkan dari langit berupa air, baik yang cair maupun yang membeku. Yakni memperhatikan proses turunnya hujan dalam siklus yang berulang-ulang, bermula dari air laut yang menguap dan berkumpul menjadi awan, menebal, menjadi dingin, dan akhirnya turun menjadi hujan, serta memperhatikan pula angin dan fungsinya, yang kesemuanya merupakan kebutuhan bagi kelangsungan dan kenyaman hidup manusia, binatang dan tumbuhtumbuhan.

\footnotetext{
${ }^{121}$ Departemen Agama, op.cit., h. 26

${ }^{122}$ M.Quraish Shihab, Tafsir Al-Misbah ..., Vol. 1, op.cit., h. 374-375
} 
5) Berfikir tentang aneka binatang yang diciptakan Allah, baik binatang berakal (manusia), ataupun tidak, menyusui, bertelur, melata dan lainlain.

Berdasarkan ayat dapat dipahami bahwa tujuan pendidikan dalam al-Quran adalah agar manusia berfikir dan menggunakan akalnya. Sehingga menurut Abuddin Nata bahwa orang yang berakal adalah orang yang melakukan dua hal yaitu: tazakkur yakni mengingat (Allah SWT), dan tafakkur yakni memikirkan (ciptaan Allah SWT). ${ }^{123}$

d. Agar ManusiaMemiliki Ilmu Pengetahuan dan Meninggikan Derajatnya Allah SWT berfirman dalam al-Quran yang artinya:

"(Apakah kamu Hai orang musyrik yang lebih beruntung) ataukah orang yang beribadat di waktu-waktu malam dengan sujud dan berdiri, sedang ia takut kepada (azab) akhirat dan mengharapkan rahmat Tuhannya? Katakanlah: "Adakah sama orang-orang yang mengetahui dengan orang-orang yang tidak mengetahui?" Sesungguhnya orang yang berakallah yang dapat menerima pelajaran”. (Q.S az-Zumar: 9)

Abuddin Nata menjelaskan bahwa pada ayat di atas, terlihat adanya hubungan orang-orang yang mengetahui (berilmu=ulama) dengan melakukan ibadah di waktu malam, takut terhadap siksaan Allah SWT di akhirat serta mengharapakan rahmat dari Allah SWT.; dan juga menerangkan bahwa sikap yang demikian itu merupakan salah satu ciri dari ulul albab, yaitu orang yang menggunakan fikiran, akal dan nalar untuk mengembangkan ilmu pengetahuan, dan menggunakan hati untuk mengarahkan dan menggunakan ilmu pengetahuan tersebut pada tujuan peningkatan akidah dan ketinggian akhlak yang mulia. ${ }^{124}$

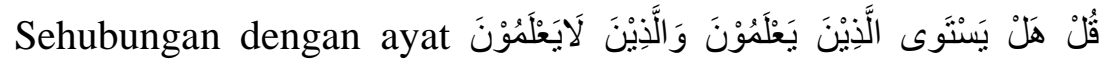
(Adakah sama orang-orang yang mengetahui dengan orang-orang yang

${ }^{123}$ Abuddin Nata, Tafsir Ayat-Ayat Pendidikan: Tafsir al-ayat al-tarbawy, (Jakarta: Rajawali Pers, 2012), h. 131

${ }^{124}$ Ibid., h. 166 
tidak mengetahui), menurut al-Maraghi sebagaimana dikutip oleh Abuddin Nata mengatakan: Katakanlah hai Rasul kepada kaummu, adakah sama orang-orang yang mengetahui bahwa ia akan mendapatkan pahala karena ketaatan kepada Tuhannya, dengan orang-orang yang tidak mengetahui hal yang demikian itu? Ungkapan pertanyaan dalam ayat ini menunjukkan bahwa yang pertama (orang-orang yang mengetahui) akan dapat mencapai derajat kebaikan; sedangkan yang kedua (orang-orang yang tidak mengetahui) akan mendapat kehinaan dan keburukan. ${ }^{125}$

Dan pada gilirannya orang-orang yang mengetahui (berilmu= ulama) itu akan diangkat derajatnya oleh Allah SWT., sebagaimana Firman-Nya yanga artinya:

Hai orang-orang beriman apabila kamu dikatakan kepadamu: "Berlapang-lapanglah dalam majlis", Maka lapangkanlah niscaya Allah akan memberi kelapangan untukmu. dan apabila dikatakan: "Berdirilah kamu", Maka berdirilah, niscaya Allah akan meninggikan orang-orang yang beriman di antaramu dan orang-orang yang diberi ilmu pengetahuan beberapa derajat. dan Allah Maha mengetahui apa yang kamu kerjakan.(Q.S al-Mujadalah: 11)

Ibnu Abi Hatim meriwayatkan dari Muqotil bahwa ayat ini turun pada hari jumat. Ketika itu, melihat beberapa sahabat yang dulunya mengikuti perang badar dari kalangan muhajirin maupun anshor. ${ }^{126}$ diantaranya Tsabit ibn Qais mereka telah didahului orang dalam hal tempat duduk. Lalu merekapun berdiri dihadapan rasulullah saw kemudian mereka mengucapakan salam dan Rasullullah menjawab salam mereka, kemudian mereka menyalami orang-orang dan orangorang pun menjawab salam mereka. mereka berdiri menunggu untuk diberi kelapangan, tetapi mereka tidak diberi kelapangan. Rasullullah

${ }^{125}$ Ibid., h. 166-167

${ }^{126}$ Jalaluddin As-Suyuthi, Sebab Turunnya Ayat Al-Qur'an, (Depok: gema insani, 2008), h.554 
merasa berat hati kemudian beliau mengatakan kepada orang-orang disekitar beliau ,"berdirilah engkau wahai fulan, berdirilah engkau wahai fulan”. Merekapun tampak berat dan ketidak enakan beliau tampak oleh mereka. kemudian orang-orang itu berkata, "demi Allah swt, dia tidak adil kepada mereka. orang-orang itu telah mengambil tempat duduk mereka dan ingin berdekat dengan Rasulullah saw tetapi dia menyuruh mereka berdiri dan menyuruh duduk orang-orang yang datang terlambat ${ }^{127}$.

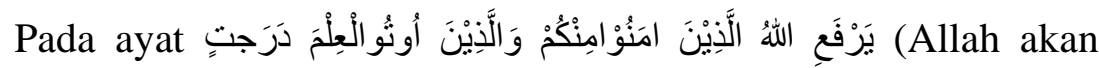
meninggikan orang-orang yang beriman di antaramu dan orang-orang yang diberi ilmu pengetahuan beberapa derajat), menurut Quraish Shihab pada ayat ini tidak menyebutkan secara tegas bahwa Allah SWT akan meninggikan derajat orang berilmu. Tetapi menegaskan bahwa mereka memiliki derajat-derajat yakni yang lebih tinggi dari yang sekedar beriman. Tidak disebutkannya kata meninggikan itu, sebagai isyarat bahwa sebenarnya ilmu yang dimilikinya itulah yang berperanan besar dalam ketinggian derajat yang diperolehnya, bukan akibat dari faktor di luar ilmu itu. ${ }^{128}$

Tentu saja yang dimaksud denganمang diberi pengetahuan) adalah mereka yang beriman dan menghiasi diri mereka dengan pengetahuan. Ini berarti ayat di atas membagi kaum beriman kepada dua kelompok besar, yang pertama, sekedar beriman dan beramal saleh, dan yang kedua, beriman dan beramal saleh serta memiliki pengetahuan. Derajat kelompok kedua ini menjadi lebih tinggi, bukan saja karena nilai ilmu yang disandangnya, tetapi juga amal dan

${ }^{127}$ Ahmad Musthofa Al-Maraghi, Terjemahan Tafsir al-Maraghi, (Semarang: Toha Putra, 1993), Jilid 28, h.23-24

${ }^{128}$ M.Quraish Shihab, Tafsir Al-Misbah: Pesan, Kesan, dan Keserasian AlQuran, (Jakarta: Lentera Hati, 2002), Vol. 14, h.79 
pengajarannya kepada pihak lain baik secara lisan, atau tulisan maupun dengan keteladanan. Ilmu yang dimaksud oleh ayat di atas bukan saja ilmu agama, tetapi ilmu apapun yang bermanfaat. ${ }^{129}$

Kata ilmu dengan berbagai bentuknya terulang 854 kali dalam al-Qur'an. Kata ini digunakan dalam arti proses pencapaian pengetahuan dan objek pengetahuan. Kata ilmu dari berbagai memiliki arti kejelasan, karena itu segala yang terbentuk dari akar katanya mempunyai ciri kejelasan. Misalnya dapat dilihat dalam contoh 'a 'lam (gunung-gunung), 'alamat dan lain sebagainya. ${ }^{130}$

Di samping itu untuk mengetahui lebih lanjut mengenai pengertian ilmu, paling tidak beberapa kata yang mengandung pengertian “tahu” seperti “'arafa,dara'a, khabara, sya'ara, basyirah, hakim. Katakata turunan dari kata 'arafa dalam al-Quran terdapat sebanyak 34 kali ${ }^{131}$ dengan berbagai bentuknya. Oleh karena itu kata 'ilmu bersinonim dengan kata ma'rifah, yang artinya tahu atau pengetahuan.

Berdasarkan uraian di atas dapat dipahami bahwa salah satu tujuan pendidikan dalam al-Quran adalah agar manusia memiliki ilmu pengetahuan, sehingga dengan memiliki ilmu pengetahuan tersebut ditambah lagi dengan mengerjakan amal saleh serta beriman kepada Allah SWT, maka derajat manusia tersebut akan ditinggikan oleh Allah SWT beberapa derajat.

e. Supaya Manusia Mendapatkan Kesejahteraan dan Kebahagian Hidup di Dunia dan di Akhirat

Allah SWT berfirman dalam al-Quran yang artinya:

\footnotetext{
${ }^{129}$ Ibid., h. 79-80

${ }^{130}$ M.Quraish Shihab, Wawasan Al-Qur'an: Tafsir Maudhu'i atas Berbagai Persoalan Umat, (Bandung: Mizan, 2004), h. 434

${ }^{131}$ Muhammad Fuad Al-Baqi, Al-Mu'jamal-Mufahras lil al-fadz al-Qur'an, (Beirut: Dar al-Fikr, 1992), h. 596
}

102 
"Dan dan carilah pada apa yang telah dianugerahkan Allah kepadamu (kebahagiaan) negeri akhirat, dan janganlah kamu melupakan bahagianmu dari (kenikmatan) duniawi dan berbuat baiklah (kepada orang lain) sebagaimana Allah telah berbuat baik, kepadamu, dan janganlah kamu berbuat kerusakan di (muka) bumi. Sesungguhnya Allah tidak menyukai orang-orang yang berbuat kerusakan”.(Q.S al-Qashash: 77) ${ }^{132}$

Dalam tafsir Jalalain ayat di atas dijelaskan bahwa (dan carilah) upayakanlah - فِيْمَا اتلكَ اللهُ (pada apa yang telah dianugerahkan Allah kepadamu) berupa harta benda - الدَّارُ الاخِرَةَ (kebahagiaan negeri a وَلََتَنَْ -

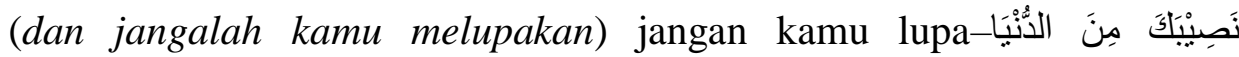
(bagianmu dari kenikmatan duniawi) yakni hendaknya kamu beramal dengannya untuk mencapai pahala di akhirat وَاََحْسِنْ- (dan berbuat baiklah) kepada orang-orang dengan bersedekah kepada mereka - كَّ

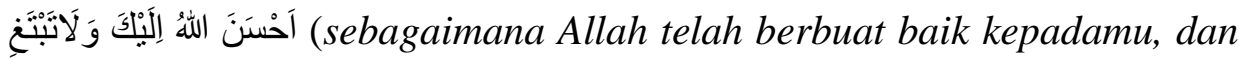
janganlah kamu berbuat) - الفَسَادفِى الأرْضِ (kerusakan di muka bumi)

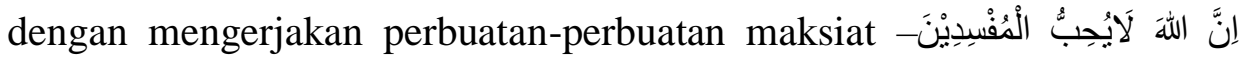
(sesungguhnya Allah tidak menyukai orang-orang yang berbuat kerusakan) maksudnya Allah pasti akan menghukum mereka ${ }^{133}$.

Terkait dengan ini, Allah SWT tegaskan pula pada ayat yang lain yang artinya:

"Dan di antara mereka ada orang yang bendoa: "Ya Tuhan Kami, berilah Kami kebaikan di dunia dan kebaikan di akhirat dan peliharalah Kami dari siksa neraka". (Q. S al-Baqarah: 201) $)^{134}$

Quraish Shihab menjelaskan bahwa bermacam-macam penafsiran ulama tentang makna hasanah di dunia dan hasanah di akhirat. Adalah bijaksana memahaminya secara umum, bukan hanya

${ }^{132}$ Departemen Agama, op.cit., h. 359

${ }^{133}$ Imam Jalaluddin Al-Mahalli dan Imam Jalaluddin As-Suyuti, Tafsir Jalalain Berikut Asbabun Nuzul, (Bandung: Sinar Baru Algensindo, 2004), jilid 2, h. 412

${ }^{134}$ Departemen Agama, op.cit., h. 32 
dalam arti iman yang kukuh, kesehatan, afiat dan rezeki yang memuaskan, pasangan yang ideal dan anak-anak yang saleh. Tetapi segala yang menyenangkan di dunia dan berakibat menyenangkan di hari kemudian. Serta bukan pula hanya keterbebasan dari rasa takut di akhirat, hisab (perhitungan) yang mudah, masuk ke surga dan mendapatkan ridha-Nya, tetapi lebih dari itu, karena anugerah Allah tidak terbatas. ${ }^{135}$

Surat al-Qashash ayat 77 dan al-Baqarah ayat 201 menjelaskan tentang Keseimbangan kebutuhan dunia dan akhirat Dunia dan akhirat merupakan dua sisi yang bertentangan tetapi keduanya tidak dapat dipisahkan dari kehidupan manusia. Dunia merupakan alat untuk mencapai ke bahagiaan akhirat. Sehingga tanpa keduniawian, kebutuhan akhirat tidak akan tercapai begitu juga tanpa kebutuhan akhirat dunia terasa hampa. Dalam mengarungi dan memenuhi kehidupan di dunia dan akhirat memerlukan tuntutan dan bimbingan. Hal itu untuk mencapai kesempurnaan dan agar tetap berada dalam jalan Allah. Dan Inilah yang menjadi salah satu tujuan pendidikan dalam al-Quran yaitu Supaya manusia mendapatkan Kesejahteraan dan Kebahagian hidup di dunia dan di akhirat.

Sebenarnya masih banyak lagi tujuan pendidikan dalam alQuran itu. Yang penulis sajikan dalam makalah ini, hanya sebagian kecil dari sekian banyaknya tujuan pendidikan dalam al-Quran.Sebagai mana pembahasan pada materi sebelumnya, bahwa semua ayat dalam al-Quran itu mengandung isyarat-isyarat tentang pendidikan. Dengan demikian dapat dipahami bahwa jika seluruh ayat al-Quran mengandung isyaratisyarat tentang pendidikan, maka seluruh ayat-ayat al-Quran itu juga mengandung tujuan-tujuan pendidikan.

${ }^{135}$ M.Quraish Shihab, Tafsir Al-Misbah ..., Vol. 1,op.cit., h. 440 


\section{Kesimpulan}

Dari uraian yang telah dikemukakan pada pembahasan di atas dapat ditarik kesimpulan sebagai berikut: Tujuan adalah sesuatu yang hendak dicapai atau diharapkan setelah melakukan sesuatu. Sedangkan tujuan Pendidikan adalah mengembangkan segala potensi bawaan manusia secara integral,silmutan,dan berkelanjutan agar manusia mampu melaksanakan tugas dan kewajiban dalam kehidupan ini guna mencapai kebahagian di masa sekarang dan masa mendatang.

Bentuk-bentuk Tujuan Pendidikan dalam al-Quran: agar manusia menjadi hamba Allah SWT, agar manusia mampu menjalankan fungsinya sebagai Khalifah Allah fi al-Ardh, agar manusia berfikir dan menggunakan akalnya, agar manusia memiliki ilmu pengetahuan dan meninggikan derajatnya, supaya manusia mendapatkan kesejahteraan dan kebahagian hidup di dunia dan di akhi

\section{Referensi}

Abdullah, Abdurrahman Saleh, Teori-teori Pendidikan Berdasarkan alQuran, Jakarta: Rineka Cipta, 2005

Ahmadi, Abu dan Nur Uhbiyati, Ilmu Pendidikan, Jakarta: PT. Rineka Cipta, 2003

Al-Baqi, Muhammad Fuad, Al-Mu'jamal-Mufahras lil al-fadz al-Qur'an, Beirut: Dar al-Fikr, 1992

Ansyar, Mohammad, Dasar-Dasar Pengembangan Kurikulum, Jakarta: Direktorat Jenderal Pendidikan Tinggi, 1989

Arifin, H.M., Ilmu Pendidikan Islam: Suatu Tinjauan Teoritis dan Praktis Berdasarkan Pendekatan Interdisipliner, Jakarta: Bumi Aksara, 1991

As-Suyuthi, Jalaluddin, Sebab Turunnya Ayat Al-Qur'an, Depok: gema insani, 2008 
Asyafah, Abbas, Proses Kehidupan Manusia dan Nilai Eksistensialnya, Bandung: Alfabeta, 2009

Daradjat, Zakiah, Ilmu Pendidikan Islam, Jakarta: Bumi Aksara, 1992

Departemen Agama, Al-Quran dan Terjemahan,Jakarta: Zikrul Hakim, 2012

Gulen, Muhammad Fethullah, Tasawuf Untuk Kita Semua: Menapaki Bukitbukit Zamrud Kalbu Melalui Istilah dalam Praktik Sufisme, Terj. Fuad Syarifuddin Nur, Jakarta: Republika, 2013

Nata, Abuddin, Tafsir Ayat-Ayat Pendidikan: Tafsir al-ayat al-tarbawy, Jakarta: Rajawali Pers, 2012

Ramayulis, Ilmu Pendidikan Islam, Jakarta: Kalam Mulia, 2013

Sanjaya, Wina, Strategi Pembelajaran, Jakarta: Kencana Prenada Media Group, 2006

Shihab, M.Quraish, Wawasan Al-Qur'an: Tafsir Maudhu'i atas Berbagai Persoalan Umat,Bandung: Mizan, 2004

Suardi, M., Pengantar pendidikan teori dan aplikasi, Jakarta: PT Indeks, 2010

Suwarno, Pengantar Umum Pendidikan, Jakarta: Rineka Cipta, 1992

Undang-Undang Republik Indonesia Nomor 20 Tahun 2003 Tentang Sistem Pendidikan Nasional (Sisdiknas), Bandung: Citra Umbara, 2003

Al-Mahalli, Imam Jalaluddin dan Imam Jalaluddin As-Suyuti, Tafsir Jalalain Berikut Asbabun Nuzul, Bandung: Sinar Baru Algensindo, 2004, jilid 2

Al-Maraghi, Ahmad Musthofa, Terjemahan Tafsir al-Maraghi, Semarang: Toha Putra, 1993, Jilid 28

Al-Qurthubi, Syaikh Imam, Tafsir Al-Qurthubi, Jakarta:PustakaAzzam, 2009

Ar-Rifa'i, Muhammad Nasib, Kemudahan dari Allah: Ringkasan tafsir Ibnu Katsir, Penerjemah Syihabuddin, Jakarta: Gema Insani Press, 2000, Jilid IV 
Shihab, M.Quraish, Tafsir Al-Misbah: Pesan, Kesan, dan Keserasian AlQuran, Jakarta: Lentera Hati, 2002, Vol. 1

M.Quraish, Tafsir Al-Misbah: Pesan, Kesan, dan Keserasian Al-Quran, Jakarta: Lentera Hati, 2002, Vol. 4

M.Quraish, Tafsir Al-Misbah: Pesan, Kesan, dan Keserasian Al-Quran, Jakarta: Lentera Hati, 2002, Vol. 13

M.Quraish, Tafsir Al-Misbah: Pesan, Kesan, dan Keserasian Al-Quran, Jakarta: Lentera Hati, 2002, Vol. 14 